Research Article

\title{
Using SIRES to Enhance Resilience in Remote \& Rural Communities
}

\author{
Zeel Maheshwari ${ }^{1,}{ }^{*}$, Rama Ramakumar ${ }^{2}$
}

1. Department of Physics, Geology and Engineering Technology, Northern Kentucky University, Highland Heights, KY, USA; E-Mail: maheshwarz1@nku.edu

2. School of Electrical and Computer Engineering, Oklahoma State University, Stillwater, USA; EMail: rama.ramakumar@okstate.edu

* Correspondence: Zeel Maheshwari; E-Mail: maheshwarz1@nku.edu

Academic Editor: Zhao Yang Dong

Special Issue: $\underline{\text { Sustainable Energy Supply for the Developing Communities }}$

Journal of Energy and Power Technology

2022, volume 4, issue 1

doi:10.21926/jept.2201006
Received: August 29, 2021

Accepted: January 17, 2022

Published: January 21, 2022

\begin{abstract}
Rural and remote communities are more vulnerable to damage caused by extreme events as compared to urban areas. Natural disasters can disrupt basic supplies such as domestic water supply and cooking needs in addition to electricity outages. The recognition of the interlinked nature of food, water and energy has gained momentum over the past few years. Smart Integrated Renewable Energy System (SIRES) has been proposed to handle basic needs such as cooking, domestic and irrigation water supply, and electricity to remote rural areas in an efficient and sustainable manner. Critical needs and non-critical needs for a typical rural community are discussed. The proposed approach is studied for two different scenarios: wind subsystem is inoperable and hydropower is inoperable due to the destruction caused by a natural disaster. In this paper, it is shown that employing SIRES could improve overall resiliency as compared to microgrids.
\end{abstract}

\section{Keywords}

Sustainable development; energization; integrated renewable energy; resilience; foodenergy-water nexus; rural communities

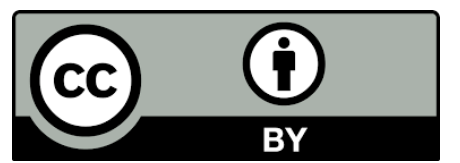

(C) 2022 by the author. This is an open access article distributed under the conditions of the Creative Commons by Attribution License, which permits unrestricted use, distribution, and reproduction in any medium or format, provided the original work is correctly cited. 


\section{Introduction}

Food, water and energy needs are the essence of overall development in rural areas. Global demand of these needs is rapidly increasing with population growth, urbanization and climate change [1]. Millions of people still lack access to these basic needs with majority living in isolated rural areas. There has been significant progress in electrification of rural areas in developing Asia since 2000. However, economic downturn and health crisis due to COVID-19 pandemic will slow down the progress especially in rural Africa. According to International Energy Agency (IEA) [2], it is projected that 660 million people may still not have access to electricity in 2030 owing to rapid population growth and difficulties due COVID-19. Moreover, around 2.6 billion people lack access to clean cooking facilities, relying instead on solid biomass, kerosene or coal as their primary cooking fuel. 785 million people lack access to basic domestic water based on World Health Organization (WHO) report [3]. By 2025, half of the world's population will be living in water-stressed areas.

In 2015, world leaders agreed to 17 Sustainable Development Goals or SDGs at UN Sustainable Development Summit. These goals have the power to create a better world by 2030, by ending poverty, fighting inequality, sustainable energy access and addressing the urgency of climate change. In particular, goal 2 addresses the hunger issue, goal 6 targets availability of safe water for all and goal 7 states the need to ensure access to affordable, reliable and sustainable energy for all [4].

The interconnections between food, energy and water sectors known as FEW nexus has received considerable attention in recent years [5]. The nexus is characterised by resource interdependencies which means that any decision that is made in one sector has an impact on other sectors. As seen in Figure 1, energy and in particular electricity is required for water treatment, distribution and pumping and food processing and storage. On the other hand, water (hydropower) and biomass obtained from food waste (biogas) can be used to produce electricity. In addition, water is also used for cooling system of power plants. Lastly, food production requires irrigation water and water quality depends on the agriculture production because of non-point source pollution.

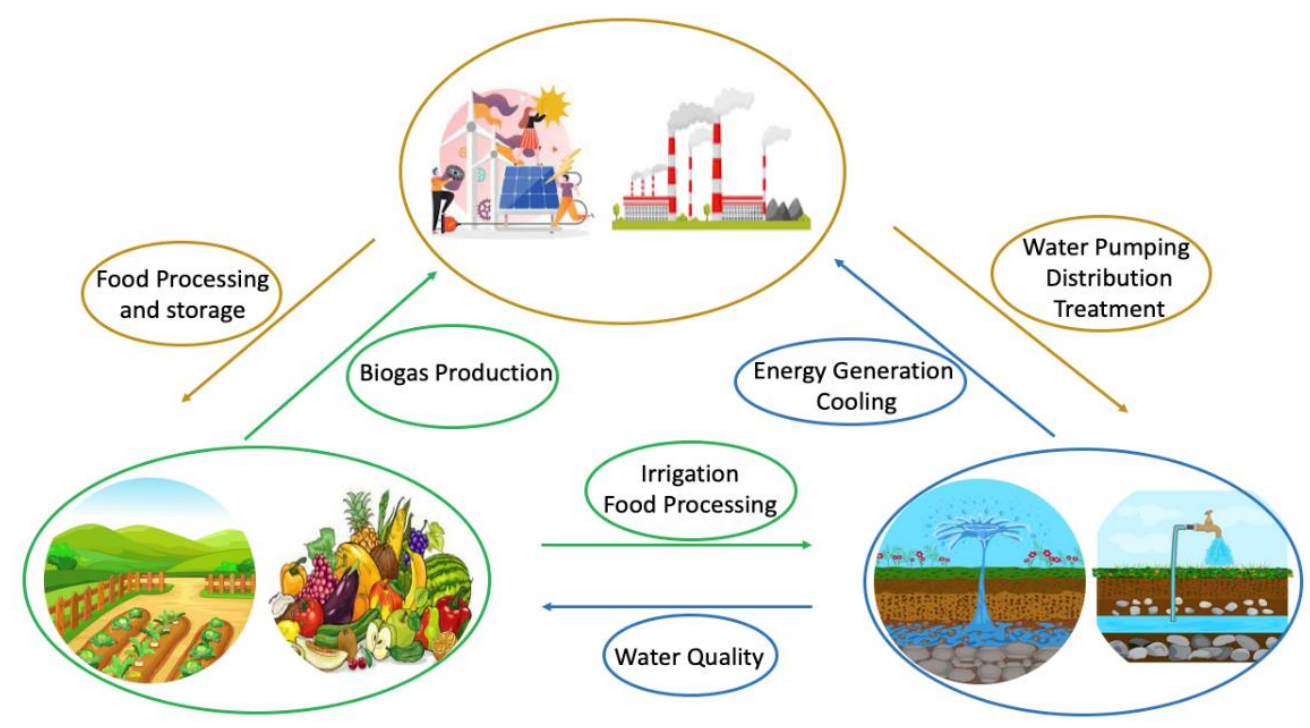

Figure 1 Interconnections of food-energy-water nexus. 
Food-Energy-Water (FEW) nexus was first mentioned by World Economic Forum in 2011 as Water-Food-Energy-Climate Nexus in "Water Initiative" report. The report states that water lies in the heart of nexus of food, energy, climate, economic growth and human security challenges that the global economy faces over the next two decades [6]. Since then, several frameworks and models have been proposed to understand the complexity of the nexus [5]. Shannak S et.al reviewed current FEW nexus models to identify key opportunities and challenges in FEW design and modelling. An overview of the processes, methods, policies and interconnections of food, water and energy resources was addressed in [7]. The authors reviewed current state of research on nexus approaches and main challenges to the implementation along with future insights are mentioned. An integrated model that captures the interactions between water, food and energy at household scale was studied by Wa'el Hussien et al. [1]. They develop models for household water consumption, energy consumption and food consumption. In addition they also studied the impact of income and seasonal variability on water, energy and food. Melissa Hang et.al proposed a methodology for the design of local production systems and developed a superstructure-based optimization model specifically for FEW nexus through a case study for a designated eco-town in UK [8]. However, none of these studies focus on using renewable energy resources for consistently fulfilling basic needs such as food, water and energy. Ebrahim Karan (2016) designed and analysed a small-scale FEW system for a typical family of four ( 2 adults and 2 children) that can collect or recycle its own water, supply energy needs powered by solar PV panels [9]. The authors optimized the system based on decision variables such as size of the system, water recycling capacity and solar system.

As seen from the above mentioned literature review, most of these studies are based on the concept of electrification. Earlier approaches such as Grid Extension, Electricity Home Systems (EHS), Hybrid Energy Systems (HES) and Microgrids have been implemented to provide electricity in rural areas [10]. However, as of now, very few systems are based on the principle of energization to meet all the basic necessities. Smart Integrated Renewable Energy System (SIRES) was proposed in [11] to fill this gap by fulfilling basic needs using local renewable energy resources such as solar energy, wind energy, biogas and water. As mentioned previously, extreme events can interrupt supplies to basic needs such as cooking and water facilities in addition to electricity outages. Hence, in this paper, a priority-based energy management technique for SIRES is proposed to improve resilience during major disasters in remote rural areas.

In section 2, state of the art of resilience for food, water and energy, more specifically electricity is presented. Renewable energy resources utilized by SIRES and basic needs expected to be fulfilled for the rural community are described in section 3. In section 4, resilience enhancement framework for SIRES is discussed. Section 5 describes results obtained for two different scenarios for SIRES and compared with results obtained for microgrid. Finally, concluding remarks are succinctly presented in section 6.

\section{State of the Art of Resilience}

Unexpected and extreme events can potentially disrupt the operations of a complete system comprising of food supply chains, water network supply, and electric power grids that are in turn supported by communications, transportation and other network infrastructures. Disruptions and system component failures can lead to negative economic, environmental and social impacts on 
unprecedented scales. Figure 2 illustrates a typical curve for performance of a system associated with an extreme event such as drought, flooding, heatwaves or winter storm. Consider Extreme Event $(E)$ occurs at incident time $\left(t_{i}\right)$. Several system components can fail as the severity of the event increases. Consider $t_{f}$ is the time of failure or the time at which system components begin to fail. A few components may work despite of the extreme event based on the Failure Probability (FP) of the component. Failure probability (FP) is described as the probability of a component to be inoperable when an extreme event occurs. As a result, partial needs are fulfilled by the system components that are operable after the event occurs. Other components are repaired or replaced as required so that the system is $100 \%$ functional by time $\left(t_{r}\right)$ or the recovery time.

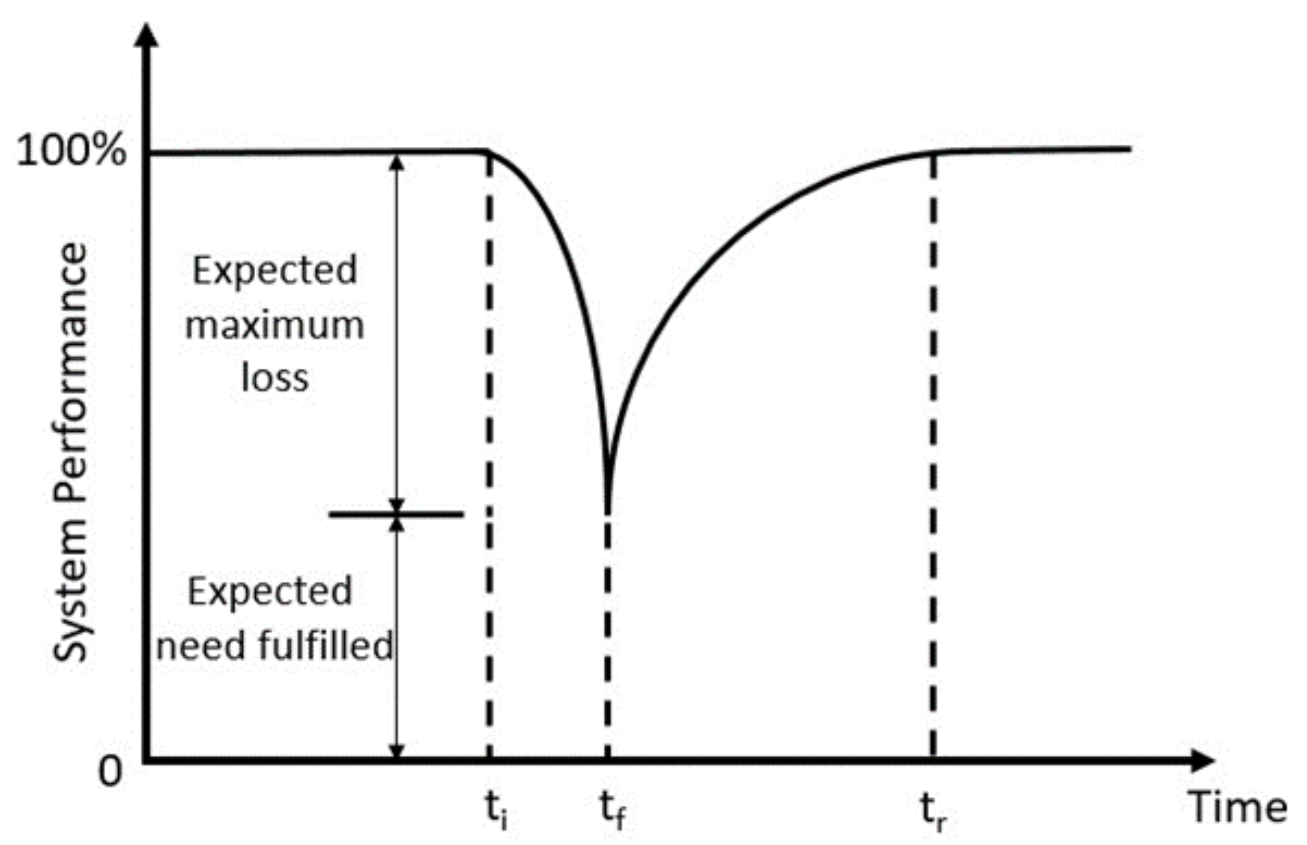

Figure 2 Typical system performance after an extreme event occurs.

Vibhas Sukhwani et.al studied the integrated decision making platforms at regional level and believe it will significantly enhance the collective resilience to emerging socio-economic challenges [12]. A novel computational framework that incorporates "algorithmic resilience thinking" to achieve adaptive and robust inter-networked FEW systems was developed in [13]. Authors in [14] mention the lack of research of FEW nexus at local level; compounding the vulnerability of FEW nexuses at local, regional and national scales.

\subsection{Resilience Aspects of Microgrids}

Existing power grid is reliable during normal conditions and low impact foreseeable contingencies. However, resilience of power grids to extreme events has been a major concern for utilities and researchers. According to the Department of Energy (DoE), weather-related power outages are up by $67 \%$ since 2000 [15]. In point of fact, outages due to extreme weather events were 73\% higher in 2020 (1.3 billion hours) as compared to 2019 (770 million hours), according to PowerOutage.US. More recently, winter storm Uri triggered blackouts forcing nearly 4 million people in Texas alone to live without electricity and heat for several days amid polar temperatures. Furthermore, domestic water and cooking facilities disruptions affected over 12 million people as 
reported by Texas Tribune [16]. Hotter heatwaves, harsh winter storms and more ferocious hurricanes linked to climate change are expected in the coming decades. Rural communities, in particular face more challenges in emergency and disaster management as compared to their urban counterparts [17]. Limited funding resources, geographic distances and lack of training opportunities are major obstacles for disaster resilience in rural communities.

Various studies are conducted to enhance the resilience of power systems against diverse natural disasters. Use of microgrids has gained popularity as the most common solution for resilience enhancement [18]. A microgrid can isolate itself when a major disruption occurs due to extreme events and supply power to critical loads. Thus, microgrids can either be used as a community resource or local resource to enhance resiliency of power grid. Several strategies to enhance the resiliency of microgrids have been developed by researchers. Liu et.al presented a framework for analysing the resilience of the power grid with integrated microgrids in extreme conditions. The authors employed Monte Carlo method to calculate resilience indices [19]. A resilience-oriented optimization strategy for networked hybrid microgrids is proposed in [20]. In addition, a resilience index was proposed to assess the capability of each microgrid to feed local critical loads during sudden power disruptions. In [21], a self-organization and decentralized energy management of a microgrid cluster islanded from main grid after a disruptive event is proposed. A study to enhance the resilience of hybrid microgrid considering feasible islanding and survivability of critical loads was conducted by [22]. An energy management system to enhance the resiliency of microgrid during islanded mode was proposed by [23]. The objective was to minimize the amount of critical loads while maximizing non-critical load served. In the above literature review, microgrids were used to enhance resilience and these studies on only focused on electrical loads. However, in this paper, SIRES was used to enhance the resilience and loads such as water for domestic and irrigation purposes and biogas for cooking in addition to electrical loads are considered.

\section{Resources and Needs}

SIRES utilizes locally available renewable resources to satisfy basic energy needs in an efficient manner by matching resources with needs a-priori. As mentioned before, past approaches have focused on electrification whereas SIRES concentrates on energization of rural areas. The terms "energization" and "electrification" have been often mistaken to be synonymous. However, as a matter of fact, Electrification can be considered as a subset of Energization. Microgrids is an example of electrification wherein all available resources are converted to electricity whereas SIRES is a version of energization. In energization, resources are directly utilized to fulfil basic needs and can generate electricity as required. As such, biogas can be directly used for cooking in preference to converting into electricity and then using it for cooking. Similarly solar and wind energy are used to pump water to overhead reservoir to serve domestic and irrigation water and to generate electricity. A possible configuration of SIRES is given in Figure 3. 


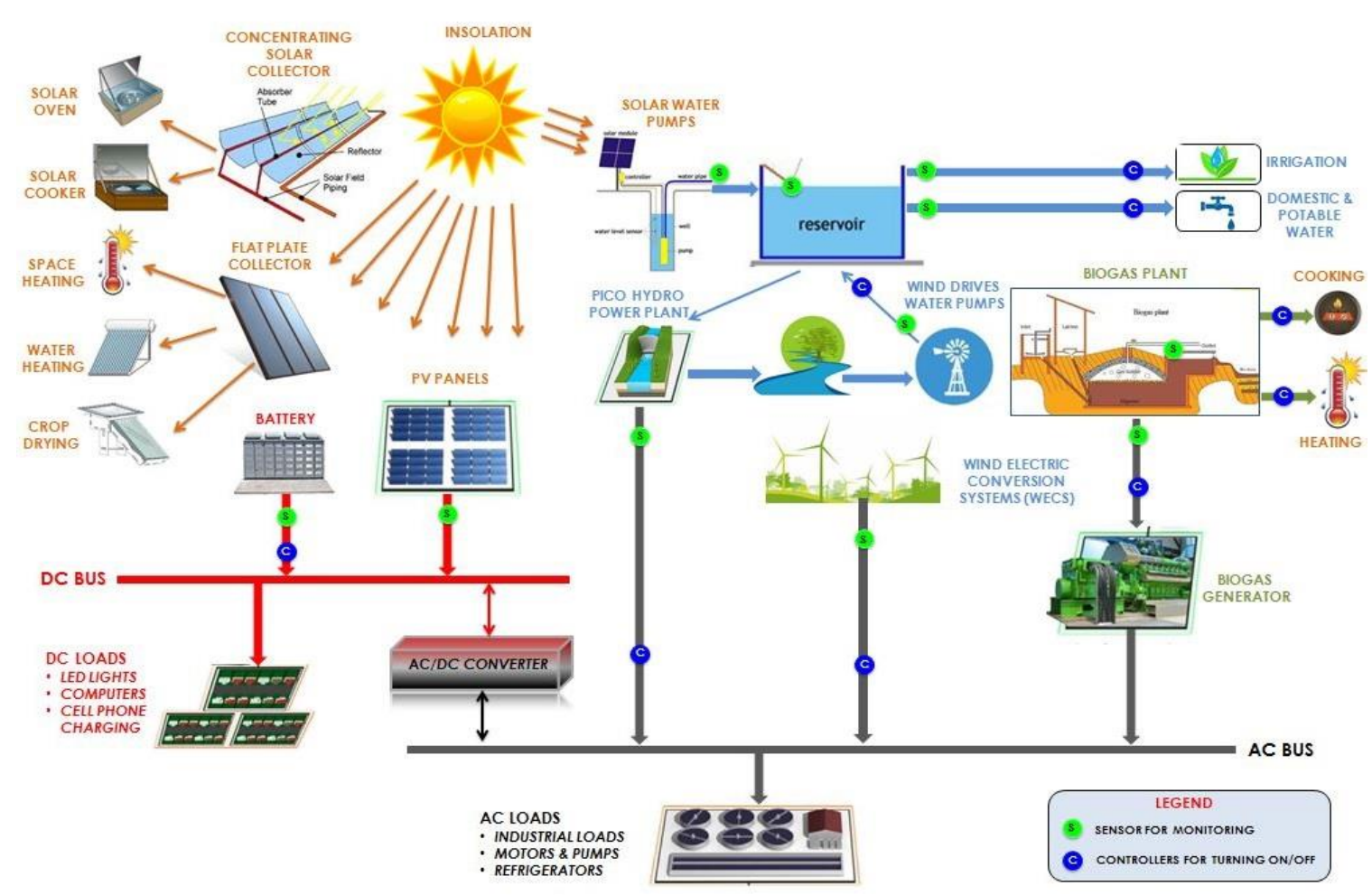

Figure 3 A possible schematic diagram of SIRES [11].

A typical remote rural area with 700 people and 450 cattle is considered in this study. It is assumed to be located at $36.1156^{\circ} \mathrm{N}, 97.0584^{\circ} \mathrm{W}$ and the area has ample water. Height of the reservoir is considered as $20 \mathrm{~m}$. Hourly solar irradiation and wind data are obtained from the Climate and Data Services, Oklahoma Climatological Survey. Typically, agriculture is the main occupation of people in rural areas. Considering 9 tons of collectible biomass (agriculture, animal and human wastes), $300 \mathrm{~m}^{3}$ of biogas can be produced daily [24]. Needs of the rural communities can be broadly classified into two types: Critical needs and non-critical needs. Basic requirements such as cooking, water for drinking and domestic purposes, lighting (domestic and community), cold storage for medicines, hospitals, low grade heating (space and water heating) and fans for ventilation are considered as critical needs. Refrigeration is not critical at the domestic level but will be in the community level for storing medical supplies. On the other hand, Small-scale industries, shops, educational institutions, communications (radio, television sets, cell phone chargers), medium grade heating (industrial process heating, crop processing) and water for irrigation purposes are considered as non-critical needs.

Based on data obtained from [25], every person requires $0.34-0.42 \mathrm{~m}^{3}$ of biogas daily for cooking. Hence for 700 people, around $250-300 \mathrm{~m}^{3}$ of biogas is required every day for cooking purposes. Since cooking is a critical need, a minimum of $250 \mathrm{~m}^{3}$ of biogas is required. Approximately $100 \mathrm{~m}^{3}$ of water is the critical water need required for domestic purposes such as drinking, personal hygiene and washing dishes [26]. 200 acres (80 hectares) of land is used for agriculture. It is estimated that $125 \mathrm{~m}^{3}$ of water is needed per hour for the entire irrigated land. However, this need is considered as non-critical when the extreme event occurs. Making electrical load projection for people who have little or no experience is difficult task. Therefore based on empirical knowledge and literature review, it is estimated that daily electrical consumption of the rural community is $375 \mathrm{kWh}$. Critical electricity needs required by the community is $175 \mathrm{kWh}$ whereas remaining $200 \mathrm{kWh}$ is considered 
as non-critical load. If microgrid is used to fulfil these basic needs, then their electrical equivalents are given in Table 1. Electricity equivalent of $0.05 \mathrm{~m}^{3}$ of biogas used for cooking is $0.17 \mathrm{kWh}$ [27]. 1 $\mathrm{kWh}$ of electrical energy can pump $9.175 \mathrm{~m}^{3}$ of water to the reservoir [28]. Pattern of energy consumption was obtained from City of Stillwater Utilities and has seasonal variations.

Table 1 Critical, non-critical and total needs for microgrid and SIRES.

\begin{tabular}{lllllll}
\hline \multirow{2}{*}{ Needs } & \multicolumn{2}{l}{ Critical Needs } & \multicolumn{2}{l}{ Non-Critical Needs } & \multicolumn{2}{l}{ Total Needs } \\
& SIRES & Microgrids & SIRES & Microgrids & SIRES & Microgrids \\
\hline Cooking (Biogas) & $250 \mathrm{~m}^{3}$ & $850 \mathrm{kWh}$ & $50 \mathrm{~m}^{3}$ & $170 \mathrm{kWh}$ & $300 \mathrm{~m}^{3}$ & $1020 \mathrm{kWh}$ \\
Water & $100 \mathrm{~m}^{3}$ & $10 \mathrm{kWh}$ & $3000 \mathrm{~m}^{3}$ & $330 \mathrm{kWh}$ & $3100 \mathrm{~m}^{3}$ & $340 \mathrm{kWh}$ \\
Electricity & $175 \mathrm{kWh}$ & $175 \mathrm{kWh}$ & $200 \mathrm{kWh}$ & $200 \mathrm{kWh}$ & $375 \mathrm{kWh}$ & $375 \mathrm{kWh}$ \\
\hline
\end{tabular}

Table 2 compares the current approaches versus technologies used in SIRES. Wind and solar energy are given the highest priority to fulfil electricity and water pumping needs. The reason to use wind and solar energy is because majority of biogas is used for cooking and water needs to be stored in reservoir to fulfil water demands.

Table 2 Current approaches versus technologies used in SIRES.

\begin{tabular}{|c|c|c|c|}
\hline Needs & Current Approach & $\begin{array}{l}\text { Technologies to be } \\
\text { used in SIRES }\end{array}$ & Priority \\
\hline Cooking & $\begin{array}{l}\text { Woodstoves, } \\
\text { Biomass, Charcoal }\end{array}$ & $\begin{array}{l}\text { Biogas obtained from } \\
\text { biogas digesters Solar } \\
\text { Cooker, Improved stoves }\end{array}$ & Critical Need \\
\hline $\begin{array}{lr}\text { Water } & \text { (drinking, } \\
\text { Domestic } & \text { and } \\
\text { community purpose) }\end{array}$ & $\begin{array}{l}\text { Hand pumps, Wells, } \\
\text { Electricity powered } \\
\text { pumps }\end{array}$ & $\begin{array}{l}\text { Wind turbines powered } \\
\text { water pumps, PV } \\
\text { powered water pumps }\end{array}$ & Critical Need \\
\hline $\begin{array}{lr}\text { Lighting } & \text { (domestic } \\
\text { and } & \text { community } \\
\text { including } & \text { street } \\
\text { lighting) } & \end{array}$ & $\begin{array}{l}\text { Oil and kerosene } \\
\text { lamps, Unreliable and } \\
\text { short duration } \\
\text { electricity }\end{array}$ & Electricity from SIRES & Critical Need \\
\hline $\begin{array}{l}\text { Cold storage for } \\
\text { medicines, hospitals }\end{array}$ & $\begin{array}{l}\text { Grid based or no } \\
\text { electricity }\end{array}$ & Electricity from SIRES & Critical Need \\
\hline $\begin{array}{l}\text { Small-scale } \\
\text { industries, shops, } \\
\text { educational } \\
\text { institutions }\end{array}$ & $\begin{array}{l}\text { Grid based or no } \\
\text { electricity, Traditional } \\
\text { methods }\end{array}$ & Electricity from SIRES & Non-Critical Need \\
\hline $\begin{array}{l}\text { Communications } \\
\text { (radio, television } \\
\text { sets, cell phone } \\
\text { chargers) }\end{array}$ & $\begin{array}{l}\text { Grid based, Battery } \\
\text { banks and charging } \\
\text { stations, solar home } \\
\text { systems, }\end{array}$ & Electricity from SIRES & Non-Critical Need \\
\hline $\begin{array}{l}\text { Low grade heating } \\
\text { (space and water } \\
\text { heating) }\end{array}$ & $\begin{array}{l}\text { Wood Charcoal, } \\
\text { Animal dung and crop } \\
\text { residues }\end{array}$ & $\begin{array}{l}\text { Flat plate solar collectors, } \\
\text { Solar crop dryers, Biogas }\end{array}$ & Critical Need \\
\hline
\end{tabular}




\begin{tabular}{|c|c|c|c|}
\hline $\begin{array}{l}\text { Medium grade } \\
\text { heating (industrial } \\
\text { process heating, crop } \\
\text { processing) }\end{array}$ & Wood, Biomass & $\begin{array}{lr}\text { Concentrated } & \text { solar } \\
\text { collectors, } & \text { Electricity } \\
\text { from SIRES } & \end{array}$ & Non-Critical Need \\
\hline $\begin{array}{l}\text { Water (irrigational } \\
\text { purpose) }\end{array}$ & $\begin{array}{l}\text { Electricity powered } \\
\text { water pumps }\end{array}$ & $\begin{array}{l}\text { Wind and Solar powered } \\
\text { water pumps, Water } \\
\text { available in reservoir, } \\
\text { Biogas driven water } \\
\text { pumps }\end{array}$ & Non-Critical Need \\
\hline Energy Storage & Battery & $\begin{array}{l}\text { Biomass and biogas } \\
\text { energy storage, Potential } \\
\text { energy in form of water, } \\
\text { Battery storage }\end{array}$ & --- \\
\hline
\end{tabular}

\subsection{Mathematical Models of System Components}

For this study, models that are presented are based on hourly values and therefore are classified as hourly models. Mathematical models of system components are represented by the equations (1)-(17) for a given day ' $i$ ' and time ' $\mathrm{t}$ '

A biogas power generation unit constitutes of a biogas-driven engine generator, biogas digesters, a biogas collection tank, controls and piping for successful operation. The energy generated by a biogas generator $\left(\mathrm{P}_{\mathrm{bio}}(\mathrm{t})\right)$ is given by:

$$
P_{b i o}(t)=\eta_{b i o} * V_{b i o} * E_{b}
$$

Where $n_{b i o}$ is efficiency of biogas generator, $V_{b i o}(t)$ is volume of biogas $\left(m^{3}\right)$, and $E_{b}$ is $5.6 \mathrm{kWh} / \mathrm{m}^{3}$ which is the energy equivalent of biogas.

If $Q_{t}\left(\mathrm{~m}^{3} / \mathrm{s}\right)$ (water flow) passes through hydro turbines, then energy generated by a picohydro power plant $\left(P_{\text {hydro }}(t)\right)$ is given by equation (2).

$$
P_{\text {hydro }}(t)=\rho_{w} * g * Q_{t}(t) * H_{d}
$$

$\rho_{w}$ is the density of water $\left(1000 \mathrm{~kg} / \mathrm{m}^{3}\right)$, g is Acceleration due to gravity $\left(9.8 \mathrm{~m} / \mathrm{s}^{2}\right)$ and $H_{d}$ is effective height of the reservoir $(m)$.

Consider a PV array consists of $\mathrm{N}_{s}$ modules in series and $\mathrm{N}_{\mathrm{p}}$ modules in parallel at an inclination angle given by $\beta$. Energy generated by $\mathrm{PV}$ panels $\left(\mathrm{Pi}_{\mathrm{PV}}(\mathrm{t}, \beta)\right)$ in $\mathrm{kWh}$ are as given below [29].

$$
\begin{gathered}
P_{P V}^{i}(t, \beta)=N_{s} * N_{p} * V_{O C}^{i}(t) * I_{S C}^{i}(t, \beta) * F F^{i}(t) \\
I_{S C}^{i}(t, \beta)=\left\{I_{S C, S T C}+K_{1}\left[T_{C}^{i}(t)-25^{\circ} C\right]\right\} * \frac{G^{i}(t, \beta)}{1000} \\
V_{O C}^{i}=V_{O C, S T C}-K_{V} * T_{C}^{i}(t) \\
T_{C}^{i}(t)=T_{A}^{i}(t)+\frac{N C O T-20^{\circ} \mathrm{C}}{800} G^{i}(t, \beta)
\end{gathered}
$$


Where $\mathrm{V}_{\text {oc }}(\mathrm{t})$ is open-circuit voltage, $\mathrm{V}_{\text {OC,STc }}$ is open-circuit voltage under Standard Test Conditions $(S T C), K_{V}$ is open-circuit temperature coefficient $(V / C), I_{s c}(t, \beta)$ is PV module short-circuit current $(A)$, ISC,STC is short-circuit current under STC $(A), G^{i}(t, \beta)$ is global irradiance $\left(W / m^{2}\right), K_{1}$ is short-circuit temperature coefficient $(A / C), T_{A}{ }_{A}(t)$ is Ambient temperature $(C), T_{C}{ }_{C}(t)$ is cell temperature $(C)$, NCOT is Nominal Cell Operating Temperature $\left({ }^{\circ} \mathrm{C}\right)$ provided by the manufacture and $\mathrm{FF}^{\mathrm{i}}(\mathrm{t})$ is Fill Factor.

Energy generated by wind turbines $\left(\mathrm{P}^{\mathrm{i}}{ }_{\mathrm{WG}}(\mathrm{t})(\mathrm{kWh})\right)$ is a function of wind speed and is presented in equation (7) [30].

$$
P_{W G}^{i}(t)=\left\{\begin{array}{lr}
P_{r} \frac{v^{i}(t, h)-v_{c}}{v_{r}-v_{c}} & v_{c} \leq v^{i}(t, h) \leq v_{r} \\
P_{r} & v_{r} \leq v^{i}(t, h) \leq v_{f} \\
0 & \text { else }
\end{array}\right.
$$

where $P_{r}$ is rated electrical power $(k W), v_{c}, v_{r}$ and $v_{f}$ cut-in, rated and cut-off wind speed in $\mathrm{m} / \mathrm{s}$ respectively. $v^{i}(t, h)$ is wind speed at desired wind turbine installation height $h$.

Modeling of wind mechanical water pump $\left(Q_{w G}(t)\right)$, PV powered water pump $\left(Q_{p v}(t)\right)$ and biogas powered water pump $\left(Q_{\text {bio }}(t)\right)$ is shown in equation $(8),(9)$ and $(10)$ respectively [31-33].

$$
\begin{gathered}
Q_{W G}^{i}(t)=\frac{1}{8} \eta_{p d} C_{p d} v^{i}(t) D_{T} \frac{\rho_{a}}{\rho_{w}}\left[\frac{G \lambda_{d}}{N_{p d}}\right] \frac{V_{d}^{3}}{g H_{d}} \\
Q_{P V}^{i}(t)=\frac{N_{S} * N_{P} * \eta_{p} * P_{P V}^{i}(t, \beta)}{\rho_{w} * g * H_{d}} \\
Q_{b i o}^{i}(t)=\frac{\eta_{\text {pump }} * \eta_{\text {engine }} * V_{\text {bio }}^{i}(t) * 5.6 * 367}{H_{d}}
\end{gathered}
$$

For wind mechanical water pump, $h_{p d}$ is efficiency of the pump at design point, $\rho_{a}$ is density of $\operatorname{air}\left(\mathrm{kg} / \mathrm{m}^{3}\right), D_{T}$ is diameter of the wind rotor $(\mathrm{m}), \mathrm{V}_{\mathrm{d}}$ is design wind velocity $\left(\mathrm{m} / \mathrm{s}^{2}\right), \mathrm{C}_{\mathrm{pd}}$ is design power co-efficient of the wind rotor, $N_{p d}$ is speed of the pump at design point $(\mathrm{m} / \mathrm{s} 2)$, $G$ is gear ratio and $\lambda_{d}$ is design tip speed ratio of the wind rotor. $\eta_{p}, \eta_{\text {pump }}$ and $\eta_{\text {engine }}$ is efficiency of PV water pump, biogas water pump and biogas engine respectively.

Battery modeling expressions are given in equations (11)-(14) [24, 30].

$$
\begin{gathered}
C_{\text {min }}=D O D * C_{n} \\
P_{B}^{i}(t)=P_{W G}^{i}(t)+P_{P V}^{i}(t, \beta)+P_{\text {hydro }}^{i}(t)+P_{\text {bio }}^{i}(t)-P_{\text {load }}^{i}(t) \\
C^{i}(t)=C^{i}(t-1)+\eta_{b} \frac{P_{B}^{i}(t)}{V_{D C, B u s}} \Delta t \\
C^{i}(24)=C^{i+1}(0)
\end{gathered}
$$

where $\mathrm{P}_{B}{ }_{B}(t)$ is battery input/output energy $(k W h), \mathrm{P}^{i_{\text {load }}}(t)$ is energy needed to fulfill the electricity load ( $\mathrm{kWh}$ ), $\mathrm{C}_{\min }$ is the minimum permissible battery capacity, DOD is maximum permissible Depth Of Discharge, $C_{n}$ is nominal capacity, $C^{i}(t)$ is available battery capacity $(A h)$ and $V_{D C, b u s}$ is $D C$ bus 
voltage $(V)$. $\eta_{\text {inverter }}$ and $\eta_{\mathrm{b}}$ is efficiency of inverter and battery respectively. $\Delta \mathrm{t}$ is simulation time step in hours and is equal to 1.

When biomass undergoes anaerobic fermentation in the digester, biogas is produced. Volume of biogas digester ( $\left.D_{v}\right)$ is given by equation (15) [24],

$$
D_{V}=\left[\text { manure }\left(\frac{m^{3}}{y e a r}\right)+\text { co }- \text { substrate }\left(\frac{m^{3}}{y r}\right)\right] * \frac{\text { retention time }(\text { days })}{365}
$$

Total electricity generated at hour $\mathrm{t}$ can be given as:

$$
P_{G e n}^{i}(t)=P_{W G}^{i}(t)+P_{P V}^{i}(t, \beta)+P_{h y d r o}^{i}(t)+P_{b i o}^{i}(t)
$$

Total amount of water pumped at hour $t$ can be given as:

$$
Q_{P \text { Pumped }}^{i}(t)=Q_{W G}^{i}(t)+Q_{P V}^{i}(t, \beta)+Q_{b i o}^{i}(t)
$$

\section{Resilience Enhancement Framework}

The prime distinction of SIRES is its focus to energize remote rural areas rather than electrify as promoted by hybrid systems and microgrids, in order to achieve sustainable development and improve the basic living environment of rural masses. Firstly, needs are prioritized based on necessities of daily life. For example, cooking would be on a higher priority when compared to electricity, and water for domestic purpose would be on a higher priority when compared to irrigation water. Secondly, resources are prioritized to fulfill needs based on availability with highest priority given to solar and wind followed by water, biogas and energy storage.

\subsection{Methodology}

The key difference between employing microgrids versus SIRES is the fact that in SIRES, the resources and needs are directly matched without going through any intermediate energy conversion before use. In microgrids, all the resources are converted to electrical form for use. A framework for energy management to enhance the resilience of SIRES is shown in Figure 4. When an extreme event occurs, available resources are identified using sensors that are strategically placed at locations where the quantity of resources have to be monitored. Electricity generated and water pumped by each system component are calculated. Based on the availability of resources, critical needs are identified and supplied at hour $t$. If critical needs cannot be satisfied, then most important "critical needs" such as electricity for hospitals, domestic water are fulfilled using stored energy and critical needs not fulfilled are calculated. After critical needs at hour $t$ are fulfilled, it is vital to store energy to ascertain that these need are continued to be fulfilled for at least 6 hours. This period gives sufficient time to replenish depleted resources. Excessive energy is used to supply non-critical needs at hour t. Surplus electrical energy and water remaining after fulfilling the critical and non-critical needs is used to store energy in form of electricity in batteries, potential energy of water in reservoir and biogas in digester. In addition, constraints such as maximum battery level, maximum reservoir capacity and maximum storage capacity of the biogas digester are considered. If any of the storage capacities are at $100 \%$, then the energy is supplied to dump load. 


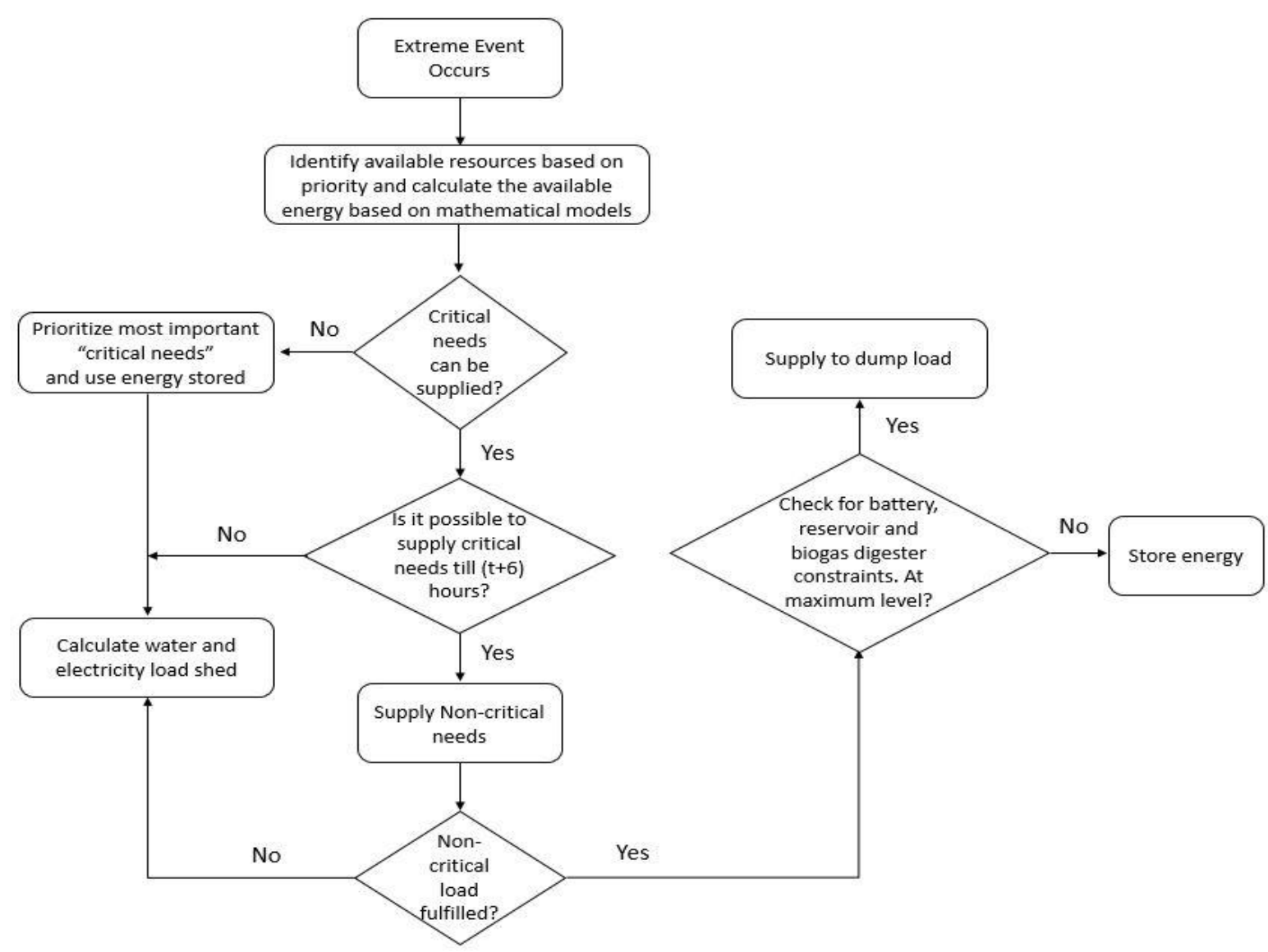

Figure 4 Priority-based Energy Management framework.

\section{Case Studies and Results}

Based on results obtained in [10] using genetic algorithm, $7.5 \mathrm{~kW}$ solar PV, 9 kW wind power, 6 $\mathrm{kW}$ biogas generator, $5 \mathrm{~kW}$ Hydropower, four Solar Water Pumps, ten wind water pumps, a biogas water pump are required for optimal operation of SIRES for minimum Annualized Cost of System (ACS) and maximum reliability. If same needs are fulfilled by microgrid (electrification), then $50 \mathrm{~kW}$ of Solar PV, $10 \mathrm{~kW}$ of wind power, $5 \mathrm{~kW}$ of biogas generator, $6 \mathrm{~kW}$ of Hydropower must be installed.

Solar PV consists of PV modules, storage (such as battery), converter, switches and inverters. Failure of either subcomponent can lead to failure of PV system. Inverters have a higher failure rate when compared to the PV modules. According to [33], after one year, a 100-kW PV has a $97.9603 \%$ probability of operating without failure, while the inverter only has $88.2497 \%$ probability. On the other hand, the reason of failure of biogas digester can be due to failure of low level switch, low level alarm, $\mathrm{O}_{2}$ controller, $\mathrm{H}_{2} \mathrm{~S}$ controller and water trap pump. Average failure probability of biogas digester per year is 0.172 [34]. Hence, due to low failure probabilities, it is assumed that solar PV and biogas are not damaged as a consequence of the extreme event. Since biogas is operational in both scenarios, it is considered that cooking need is fulfilled by SIRES since it is given highest priority. Remaining biogas is used to fulfill water and electricity needs. Two different cases are considered to evaluate the effectiveness of the proposed energy management to improve resilience. Same energy management strategy is applied to SIRES and microgrid. MATLAB software was used to implement energy management algorithm. 


\subsection{Scenario 1-Wind Subsystem is Non-Operational}

Wind turbine subsystem constitutes of rotor, blades, controllers, power module, drive train and auxiliary system. Failure in any one of these subcomponents will lead to failure in wind turbines. Failure probability for a geared wind turbine below $1 \mathrm{MW}$ rated capacity per year is 0.46 [35]. In this scenario, it is considered that wind subsystem consisting of wind turbines and wind powered water pumps is non-operational when extreme even occurs. Therefore, $Q_{W G}^{i}(t)$ and $P_{W G}^{i}(t)$ are equal to zero in equations 16 and 17 . Electricity generated by solar, biogas and hydropower in SIRES is depicted in Figure 5. It can be observed that majority of the critical electricity needs, total needs and water needs are not fulfilled around 20:00 since there is no availability of solar energy for water pumping or electricity needs. On the other hand, there is high demand for electricity and water during the same time duration. This holds true for both SIRES and microgrid. However, SIRES is more successful in satisfying critical loads when compared to microgrid. Overall, $7.27 \mathrm{kWh}$ of critical electrical loads and $124.4 \mathrm{kWh}$ of total electrical loads are shed if the wind subsystem fails in SIRES.

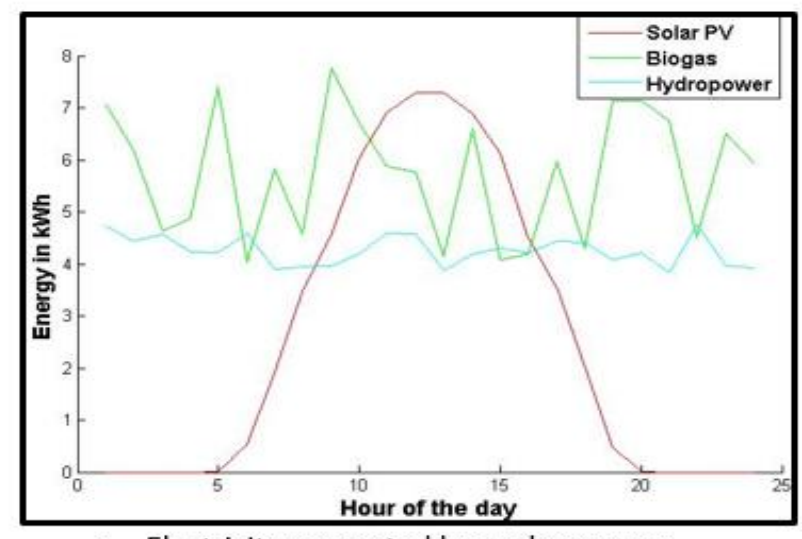

a. Electricity generated by each resource

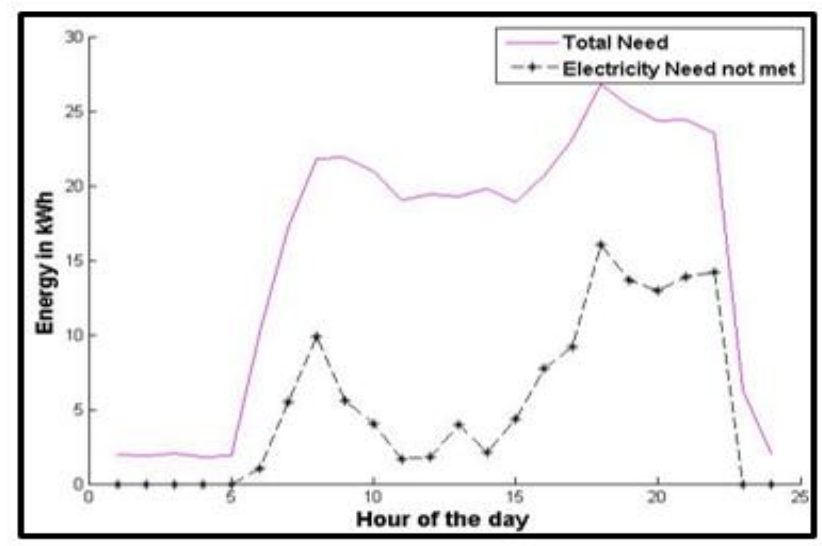

c. Total electricity need not fulfilled

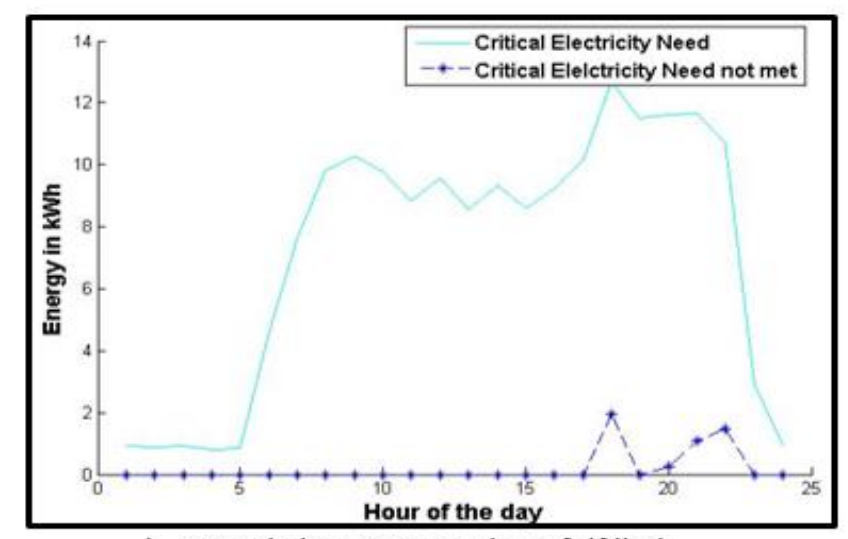

b. Critical electricity need not fulfilled

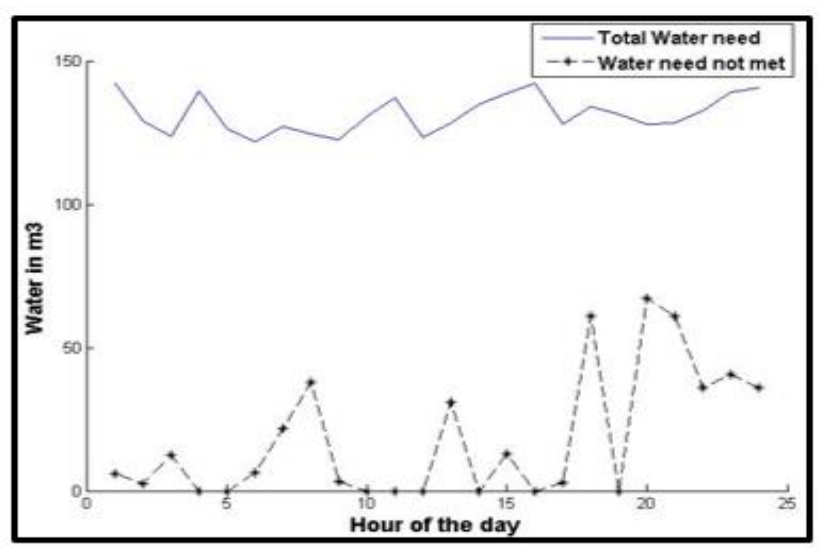

d. Total water need not fulfilled

Figure 5 Results obtained for scenario 1 for SIRES.

Critical domestic water needs are completely fulfilled although wind powered water pumps are non-operational. However, $650 \mathrm{~m}^{3}$ of irrigation water requirements is not fulfilled by SIRES. If microgrids is installed instead of SIRES, then $161.94 \mathrm{kWh}$ of critical load and $382.53 \mathrm{kWh}$ of total load is not fulfilled when wind turbine is inoperable. Electricity generated by each renewable energy and critical load not fulfilled by microgrid are depicted in Figure 6. 


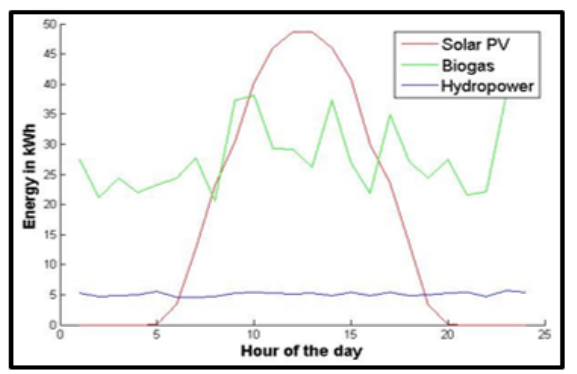

a. Electricity generated by each resource
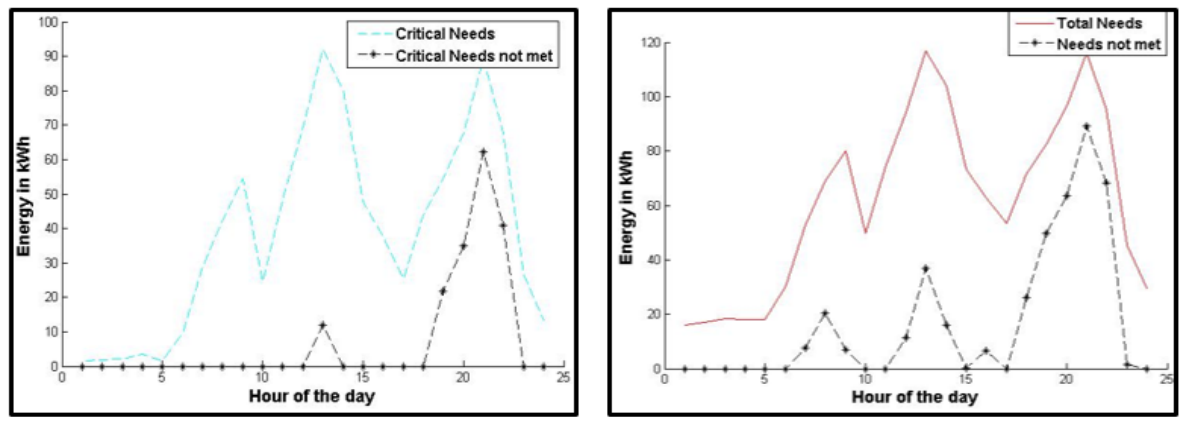

b. Critical Electricity Need not fulfilled

c. Total electricity need not fulfilled

Figure 6 Results obtained for scenario 1 for microgrid.

\subsection{Scenario 2-Hydropower is Non-Operational}

Pumped storage hydropower can fail if there is a failure in turbines, valves, generator, governor, air compressor, exciter and automatic control. Failure probability of pumped hydro storage is 0.33 [36]. In this scenario, it is considered that hydropower is non-operational when extreme event occurs. Therefore, $\mathrm{P}_{\text {hydro }}^{\mathrm{i}}$ is equal to zero in equation 16. From Figure 7 , it can be observed that no critical electrical load is shed if hydropower is inoperable.

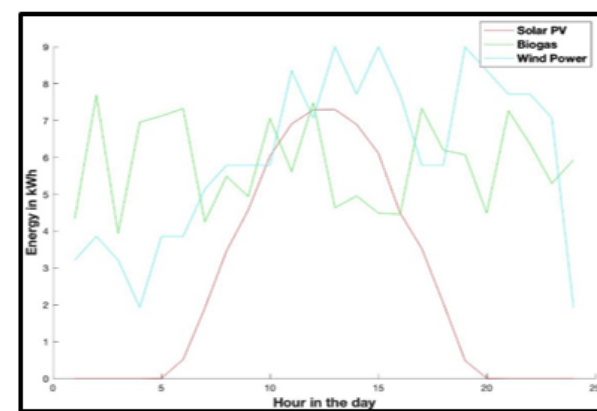

a. Electricity generated by each resource

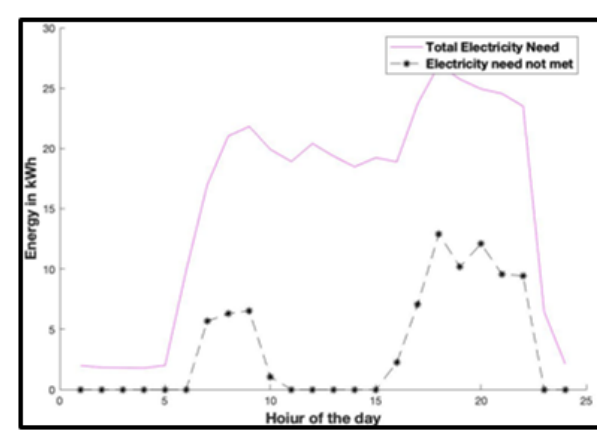

c. Total electricity need not fulfilled

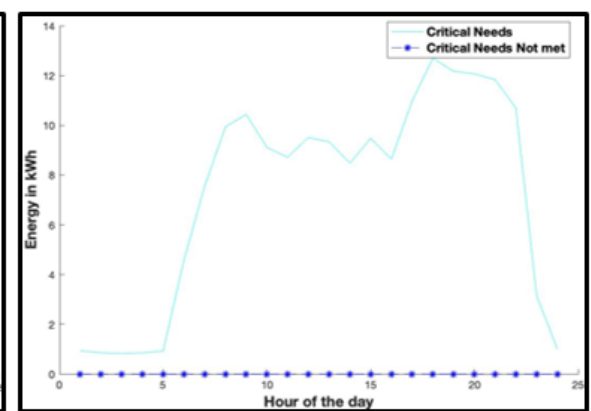

b. Critical electricity need not fulfilled

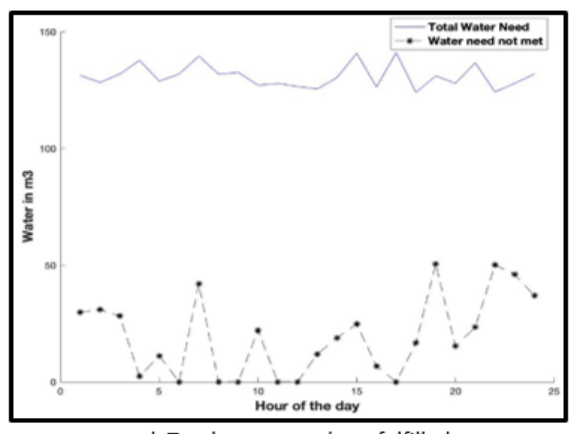

d. Total water need not fulfilled

Figure 7 Results obtained for scenario 2 for SIRES. 
However, $83 \mathrm{kWh}$ of total electrical loads are shed if hydropower fails in SIRES. Critical domestic water needs is completely fulfilled. In addition, it is observed that there is an increase in the amount of irrigation water fulfilled since wind water pumps are operational. $532 \mathrm{~m}^{3}$ of irrigation water requirements is not fulfilled by SIRES since water is stored in reservoir for emergency purposes. If hydropower is inoperable in microgrids, then $135.21 \mathrm{kWh}$ of critical load and $349.26 \mathrm{kWh}$ of total load is not fulfilled. Electricity generated by each renewable energy and critical load not fulfilled by microgrid for scenario 2 are depicted in Figure 8.

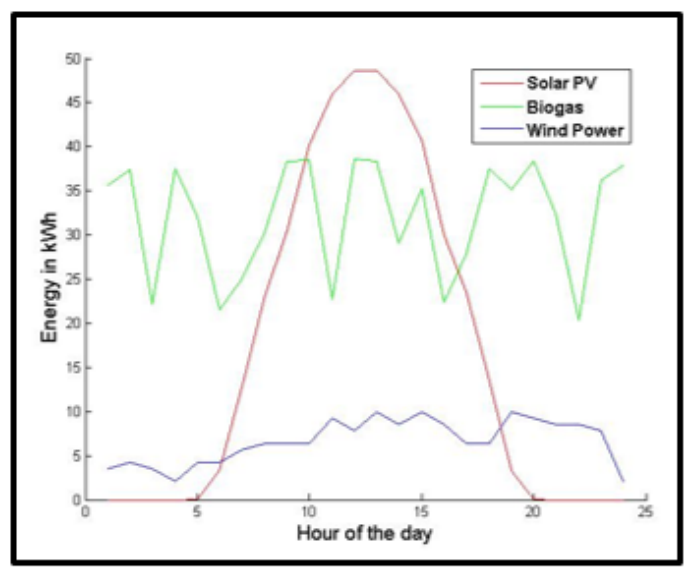

a. Electricity generated by each resource

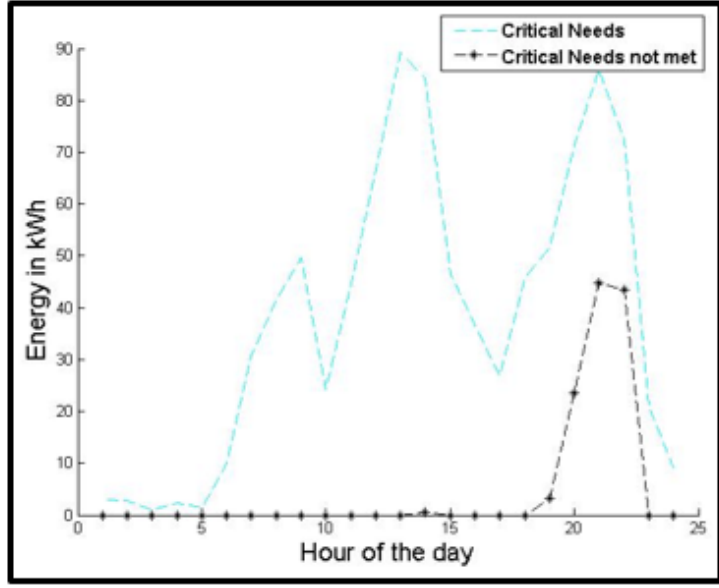

b. Critical Electricity Need not fulfilled

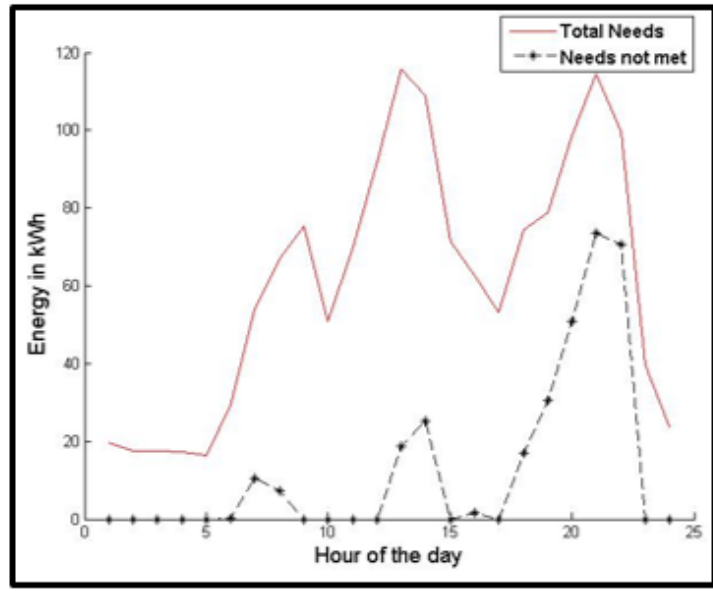

c. Total electricity need not fulfilled

Figure 8 Results obtained for scenario 2 for microgrid.

Table 3 and Table 4 summarizes the results obtained for microgrid and SIRES. From the above scenarios, it is evident that SIRES fulfills more needs when an extreme event occurs when compared to microgrid even if same energy management algorithm is applied. Therefore, it can be inferred that using SIRES enhances resilience as compared to microgrid.

Table 3 Critical and total needs not fulfilled by microgrid.

\begin{tabular}{lll}
\hline Microgrid & Scenario 1 & Scenario 2 \\
\hline Critical Needs not met & $161.94 \mathrm{kWh}$ & $135.21 \mathrm{kWh}$ \\
Total needs not met & $382.53 \mathrm{kWh}$ & $349.26 \mathrm{kWh}$ \\
\hline
\end{tabular}


Table 3 Critical and total needs not fulfilled by SIRES.

\begin{tabular}{lll}
\hline SIRES & Scenario 1 & Scenario 2 \\
\hline $\begin{array}{l}\text { Critical Water Needs } \\
\text { not met }\end{array}$ & $0 \mathrm{~m}^{3}$ & $0 \mathrm{~m}^{3}$ \\
$\begin{array}{l}\text { Total Water needs not } \\
\text { met }\end{array}$ & $650 \mathrm{~m}^{3}$ & $532 \mathrm{~m}^{3}$ \\
$\begin{array}{l}\text { Critical Electricity } \\
\text { Needs not met }\end{array}$ & $7.27 \mathrm{kWh}$ & $0 \mathrm{kWh}$ \\
$\begin{array}{l}\text { Total Electricity } \\
\text { needs not met }\end{array}$ & $124.24 \mathrm{kWh}$ & $83 \mathrm{kWh}$ \\
\hline
\end{tabular}

\subsection{Energy Storage}

The pattern of energy storage is different for critical loads and non-critical loads is different. When an extreme event occurs, the main aim is fulfil critical loads which are extremely important for human survival. Therefore, energy storage such as battery and water in reservoir are used to fulfil critical needs if the resources are insufficient. If the energy storage can fulfil requirements for a minimum 6 hours, then other non-critical needs are fulfilled. Figure 9 and 10 represent the pattern of energy storage such as water in reservoir and battery bank during the fulfilment of critical needs and non-critical needs respectively. As observed in Figure 9, electricity is discharged from battery during peak hours (7pm-9pm). It is observed that more water is discharged to fulfil non-critical loads. Similarly, higher amount of electricity is discharged from battery banks to fulfil non-critical loads.

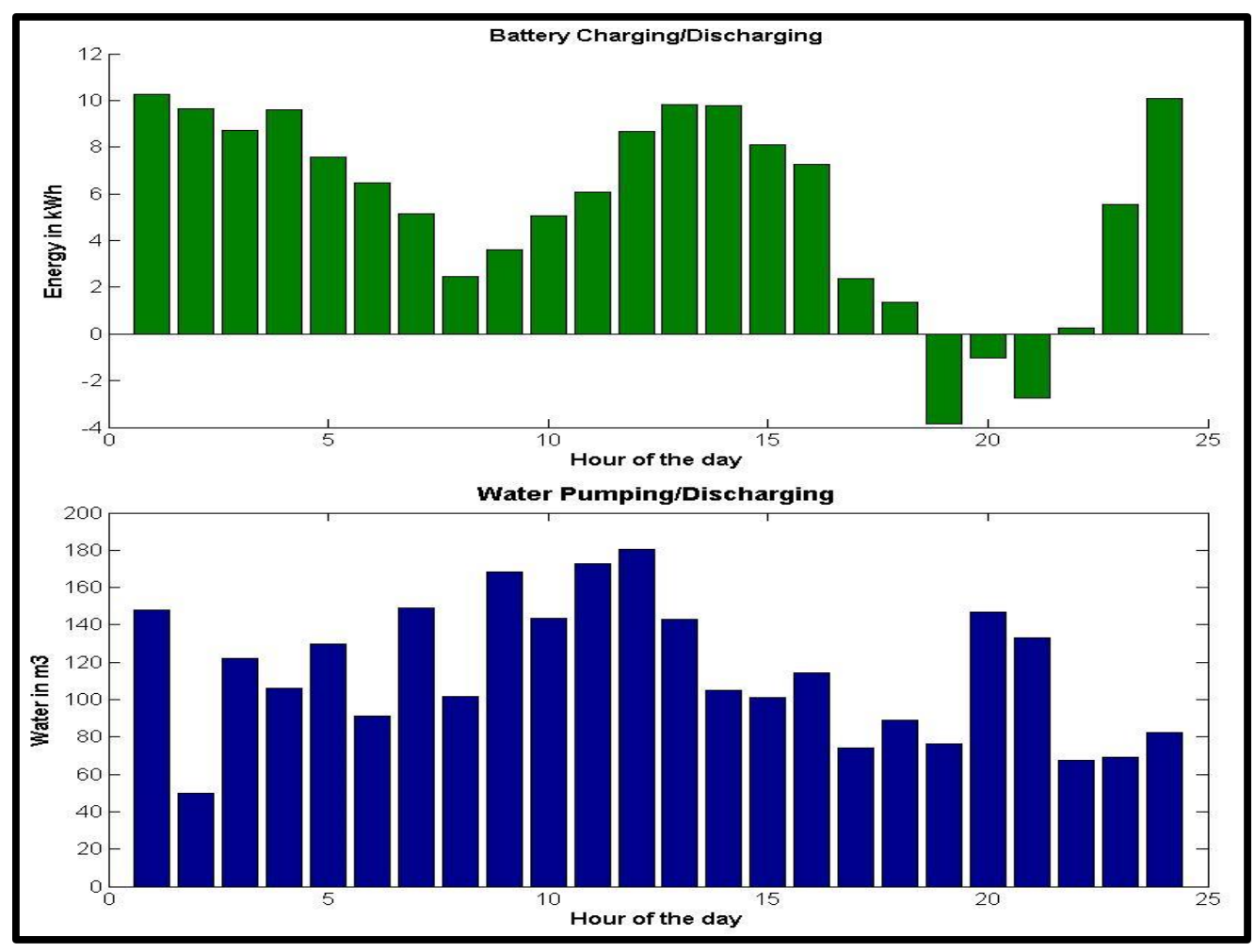

Figure 9 Energy storage pattern to fulfil critical loads. 


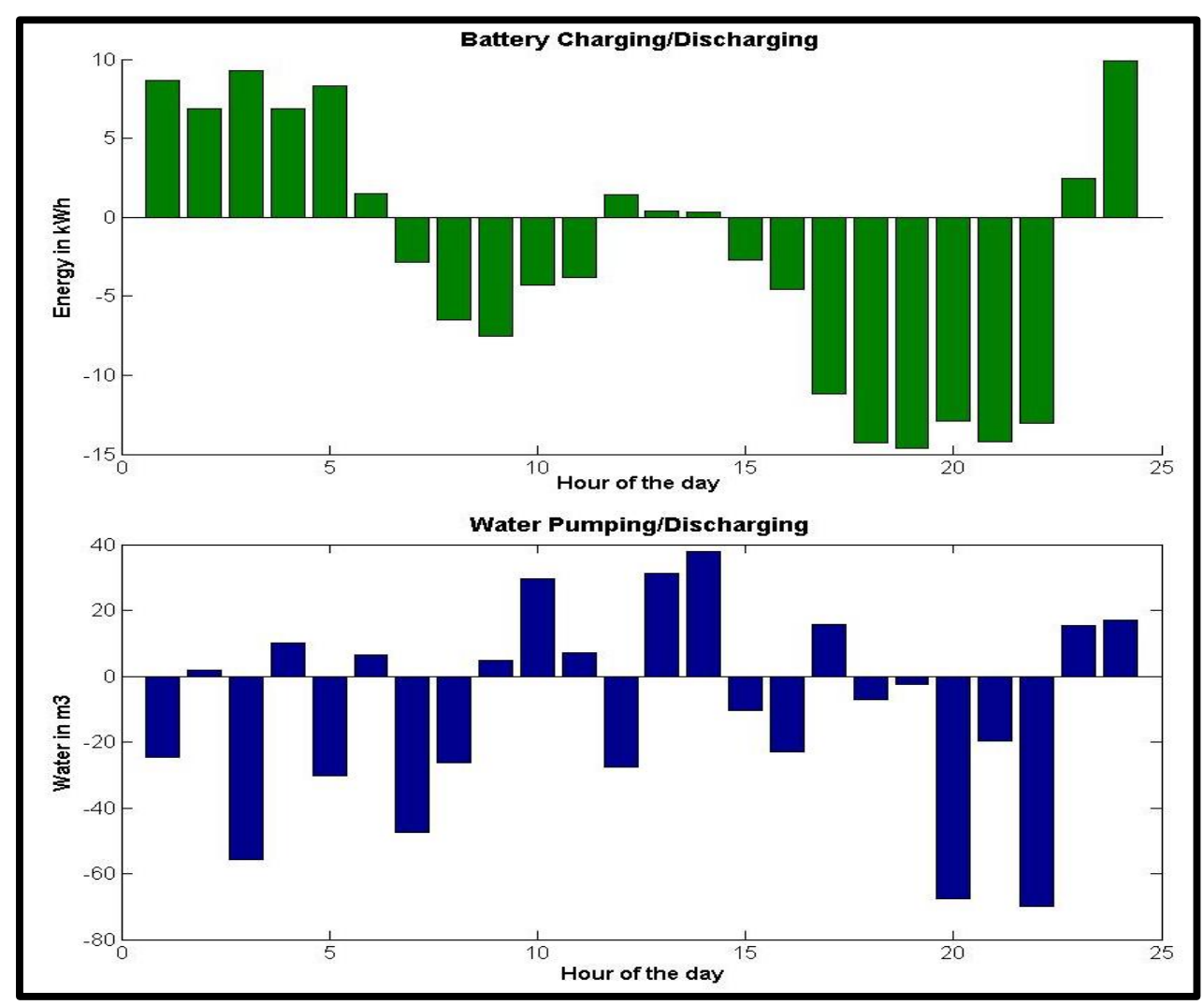

Figure 10 Energy pattern for non-critical loads.

\section{Conclusions}

The realization of food, water and energy nexus is a reminder that there is transition of scientific thought towards integrative thinking to address global challenges. One of the major challenges is natural disasters which can cause significant interruptions in water supply, electrical grids and food supply. Rural communities in particular tend to face more difficulties responding to disasters due to financial constraints and a lack of training and equipment. This study aims to propose an energy management framework to enhance resilience in remote rural communities by employing a Smart Integrated Renewable Energy Systems (SIRES). A detailed analysis of critical loads, non-critical loads and resources is presented. Implementation of this framework focuses on the critical needs such as cooking needs, domestic water and electricity for lighting, hospitals and heating. Simulations were conducted for two different scenarios based on higher probability of failure rates of system components if an extreme event occurs. Critical needs and total needs not fulfilled by SIRES and microgrids were compared and analysed. Since there is no SIRES in operation anywhere, this paper discuss hypothetical cases to illustrate the possibility of improving resilience. From the results, it was found that SIRES fulfils more critical needs and non-critical needs when compared to microgrids. Hence, SIRES performs better in enhancing resilience as compared to microgrids in remote and rural communities.

\section{Author Contributions}

Zeel Maheshwari: Main author including paper writing and results; Rama Ramakumar: Gave suggestions for improvement and proofreading the paper. 


\section{Competing Interests}

The authors have declared that no competing interests exist.

\section{References}

1. Hussien WA, Memon FA, Savic DA. An integrated model to evaluate water-energy-food nexus at a household scale. Environ Model Softw. 2017; 93: 366-380.

2. International Energy Access. SDG7: Data and projections-access to electricity [Internet]. Paris: International Energy Access; 2020. Available from: https://www.iea.org/reports/sdg7-dataand-projections/access-to-electricity.

3. World Health Organization. Drinking water [Internet]. Geneva: World Health Organization; 2019. Available from: https://www.who.int/news-room/fact-sheets/detail/drinking-water.

4. United Nations. Decisions by topic: Rural development [Internet]. New York: United Nationssustainable development knowledge platform. Available from: https://sustainabledevelopment.un.org/topics/ruraldevelopment/decisions.

5. Mabrey D, Vittorio M. Moving from theory to practice in the water-energy-food nexus: An evaluation of existing models and frameworks. Water Energy Nexus. 2018; 1: 17-25.

6. World Economic Forum Water Initiative. Water security: The water-energy-food-climate nexus. Washington: Island Press; 2012.

7. Abdi H, Shahbazitabar M, Mohammadi-Ivatloo B. Food, energy and water nexus: A brief review of definitions, research, and challenges. Inventions. 2020; 5: 56.

8. Hang MY, Martinez-Hernandez E, Leach M, Yang A. Designing integrated local production systems: A study on the food-energy-water nexus. J Clean Prod. 2016; 135: 1065-1084.

9. Karan E, Asadi S, Mohtar R, Baawain M. Towards the optimization of sustainable food-energywater systems: A stochastic approach. J Clean Prod. 2018; 171: 662-674.

10. Maheshwari Z, Ramakumar R. Smart integrated renewable energy systems (SIRES): A novel approach for sustainable development. Energies. 2017; 10: 1145.

11. Maheshwari Z, Ramakumar R. Smart Integrated Renewable Energy System (SIRES) for rural communities. Proceedings of the IEEE PES General Meeting 2016; 2016 July 17th-21st; Boston, USA. Piscataway Township: Institute of Electrical and Electronics Engineers.

12. Sukhwani V, Shaw R, Mitra BK, Yan W. Optimizing Food-Energy-Water (FEW) nexus to foster collective resilience in urban-rural systems. Prog Disaster Sci. 2019; 1: 100005.

13. Govindan R, Al-Ansari T. Computational decision framework for enhancing resilience of the energy, water and food nexus in risky environments. Renew Sust Energ Rev. 2019; 112: 653668.

14. Hibbett E, Rushforth R, Roberts E, Ryan S, Pfeiffer K, Bloom N, et al. Citizen-led community innovation for food energy water nexus resilience. Front Environ Sci Eng. 2020; 8. Doi: 10.3389/fenvs.2020.571614.

15. Kenward A, Raja U. Blackout: Extreme weather, climate change and power outages [Internet]. Princeton: Climate Central; 2014. Available from: https://assets.climatecentral.org/pdfs/PowerOutages.pdf.

16. Nearly 12 million Texans now face water disruptions. The state needs residents to stop dripping taps. [Internet]. Austin: The Texas Tribune; 2021. Available from:

https://www.texastribune.org/2021/02/17/texas-water-boil-notices/. 
17. Kapucu N, Hawkins CV, Rivera FI. Disaster preparedness and resilience for rural communities. Risk Hazards Crisis Public Policy. 2013; 4: 215-233.

18. Hussain A, Bui VH, Kim HM. Microgrids as a resilience resource and strategies used by microgrids for enhancing resilience. Appl Energy. 2019; 240: 56-72.

19. Liu X, Shahidehpour M, Li Z, Liu X, Cao Y, Bie Z. Microgrids for enhancing the power grid resilience in extreme conditions. IEEE Trans Smart Grid. 2016; 8: 589-597.

20. Hussain A, Bui VH, Kim HM. A resilient and privacy-preserving energy management strategy for networked microgrids. IEEE Trans Smart Grid. 2016; 9: 2127-2139.

21. He M, Giesselmann M. Reliability-constrained self-organization and energy management towards a resilient microgrid cluster. Proceedings of the 2015 IEEE Power \& Energy Society Innovative Smart Grid Technologies Conference; 2015 February 18th; Washington, USA. Piscataway Township: Institute of Electrical and Electronics Engineers.

22. Hussain A, Bui VH, Kim HM. Optimal operation of hybrid microgrids for enhancing resiliency considering feasible islanding and survivability. IET Renew Power Gener. 2017; 11: 846-857.

23. Balasubramaniam K, Saraf $P$, Hadidi R, Makram EB. Energy management system for enhanced resiliency of microgrids during islanded operation. Electr Power Syst Res. 2016; 137: 133-141.

24. Caslin B. Potential of farm scale AD in Ireland [Internet]. Carlow: Agriculture and Food Development Authority; 2009. Available from: https://silo.tips/download/tullamore-courthotel-october-22-nd-barry-caslin-teagasc-bioenergy-specialist.

25. Brown NL, Tata PB, Energy Research Group. Biomethanation. In: Bioenergy. Ottawa: International Development Research Centre; 1990. pp.111-117.

26. Fan L, Liu G, Wang F, Geissen V, Ritsema CJ. Factors affecting domestic water consumption in rural households upon access to improved water supply: Insights from the Wei River Basin, China. PloS ONE. 2013; 8: e71977.

27. Dutt GS, Ravindranath NH. Bioenergy: Direct applications in cooking. In: Renewable energy: Sources of fuels and electricity. Washington: Wiley Eastern Limited; 1993. pp.676-677.

28. Gad HE, Safya M. Using photovoltaic array for solar water pumping in Toshka Region, Egypt. Proceedings of the 15th International Water Technology Conference; 2011 March 31st-April 2nd; Alexandria, Egypt. Alexandria: International Water Technology Conference.

29. Lotfi S, Tarazouei FL, Ghiamy M. Optimal design of a hybrid solar-wind-diesel power system for rural electrification using imperialist competitive algorithm. Int J Renew Energy Res. 2013; 3: 403-411.

30. Koutroulis E, Kolokotsa D, Potirakis A, Kalaitzakis K. Methodology for optimal sizing of standalone photovoltaic/wind-generator systems using genetic algorithms. Sol Energy. 2006; 80: 1072-1088.

31. Fraenkel PL. Water lifting devices. Rome: Food and Agriculture Organization of the United Nations; 1986. pp.31-32.

32. Mathew S, Pandey KP. Modelling the integrated output of wind-driven roto-dynamic pumps. Renew Energ. 2003; 28: 1143-1155.

33. Sayed A, El-Shimy M, El-Metwally M, Elshahed M. Reliability, availability and maintainability analysis for grid-connected solar photovoltaic systems. Energies. 2019; 12: 1213.

34. Torretta V, Copelli S, Contini S, Rada EC. Safety and reliability in biogas plants. Trans Built Environ. 2015; 151: 227-238. 
35. Reder MD, Gonzalez E, Melero JJ. Wind turbine failures-tackling current problems in failure data analysis. J Phys Conf Ser. 2016; 753: 072027.

36. Yasuda M, Watanabe S. How to avoid severe incidents at hydropower plants. Int J Fluid Mach Syst. 2017; 10: 296-306.

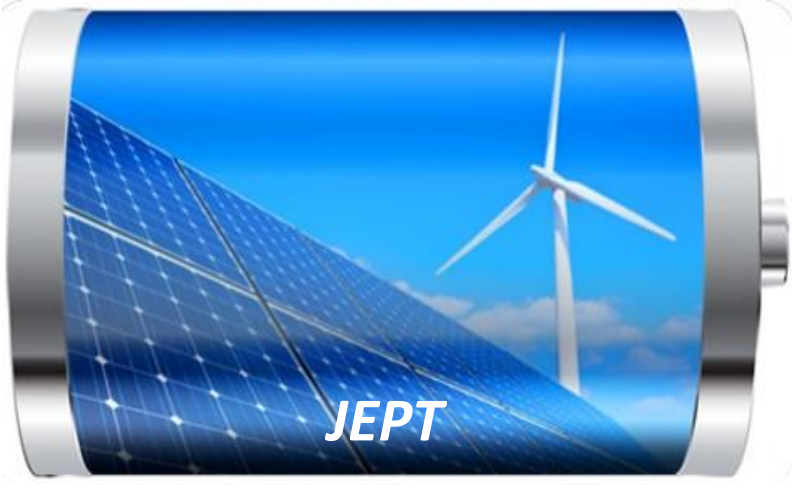

Enjoy JEPT by:

1. Submitting a manuscript

2. Joining in volunteer reviewer bank

3. Joining Editorial Board

4. Guest editing a special issue

For more details, please visit:

http://www.lidsen.com/journal/jept 